\title{
Use of leader lengths and diameters to estimate production and utilization of Cercocarpus breviflorus
}

\author{
EL FATIH MAHGOUB, REX D. PIEPER, AND MELCHOR ORTIZ
}

\begin{abstract}
Weight relations for twig lengths and diameters were determined for hairy mountain mahogany plants in southern New Mexico. Both twig lengths and twig diameters were related linearly to twig weights. Twig length and twig diameters explained more than $80 \%$ of the variation in twig weight. The equation $\hat{y}(s)=-0.68+0.3$ (length) + 6.33 (diameter) resulted in the highest $r^{2}(0.88)$ value compared to either length or diameter alone. Thus, twig length and diameter measurements could be used to determined production and utilization of hairy mountain mahogany. These relationships probably, however, vary with environmental context.
\end{abstract}

Key Words: hairy mountain mahogany, twig length diameter relationships

Authors are former graduate student, professor of range science, and associate dean and director, College of Agriculture and Home Economics, New Mexico State University, Las Cruces 88003 .

Journal article 1182 of the New Mexico Agr. Exp. Sta.

Manuscript accepted 29 Oetober 1987.
Estimating current production and utilization of shrubby species poses difficult problems for those managing shrub ranges. Shrubs are often large plants which are difficult to harvest. They frequently exhibit indeterminant growth during the current season which is often difficult to distinguish from that produced during previous growing seasons. Consequently, techniques other than clipping have been developed for determining production and utilization of important browse species.

One approach has been to work with individual branches or leaders of the shrub. In this case, twig length and diameter have been related to twig weight (Telfer 1969, Lyon 1970, Ferguson and Marsden 1977, and Provenza and Urness 1981). The procedure involves determining the relationship between length or diameter and twig weight. Production can then be estimated from length or diameter measurements alone. Individual twig weights would need to be multiplied by twig numbers for entire shrubs to express biomass on an area basis.

Length: diameter and weight:diameter ratios offer considerable 
Table 1. Rezresdon equations for best models prediethe leader welght for hairy mountain mahogany.

\begin{tabular}{lccccc}
\hline \hline & & & & Standard Error & \\
\cline { 3 - 5 } Equation & $r^{2}$ & Intercept & Slope & Length & Diameter \\
\hline$\hat{y}$ (grams) $=-.08+10.03$ (diameter) & 0.85 & 0.005 & .381 & - & - \\
$\hat{y}$ (grams) $=-0.32+0.08$ (length) & 0.80 & 0.004 & 0.003 & - & - \\
$\hat{y}$ (grams) $=-0.68+0.03$ (length) +6.33 & 0.88 & 0.052 & - & 0.005 & 0.681 \\
\begin{tabular}{l} 
(diameter) \\
\hline
\end{tabular}
\end{tabular}

promise for estimating utilization solely from post-browsing measurements. Diameter measurements after browsing provide estimates of total twig length and weight before browsing. The remaining portion of the twig can be clipped and weighed, its length and percentage utilization easily computed (Basile and Hutchings 1966). It may also be possible to estimate utilization by measuring diameter of the twig at the point where it was browsed and estimating the weight of that portion removed. Measurement of diameter at that point of attachment would allow one to estimate the weight of the intact twig.

The objective of this study was to determine length:weight and diameter:weight relations of hairy mountain mahogany (Cercocarpus breviflorus [Gray] Wright), one of the most important browse species in New Mexico.

\section{Description of Area}

The study site was located in the Organ Mountains Recreation Lands in Dona Ana County, approximately $45 \mathrm{~km}$ northeast of Las Cruces, New Mexico. The study area consisted of approximately 20 ha immediately north of the Bureau of Land Management picnic site. The elevation of the area ranges between 1,219 and $2,743 \mathrm{~m}$ at Organ Peak.

The climate of the region is characterized by mild winters, hot summers, and dry, windy springs. Most winter moisture is a result of low-intensity rains or occasionally snow. Summer precipitation occurs as a result of convectional thunderstorms of high intensity (Paulsen and Ares 1962). The majority of the annual rainfall (55\% of the average annual precipitation) is received during the period from July through September (Herbel et al. 1974).

There are no available climatic data for the Organ Mountain Recreation Lands. Generally, it can be assumed that higher elevations receive more moisture and have less extreme summer temperatures, while winter temperatures are more extreme and solar radiation is more intense than on areas at lower elevations (Moir 1963).

Vegetation of the study area was described by Moir (1963). Tall hairy mountain mahogany shrubs dominate the area, constituting approximately $44 \%$ of the shrub composition. The canopy varies from dense to widely spaced. On more favorable drainages or less exposed areas, Quercus grisea Liebm. and Garrya wrightii Torr. prevail. The understory small shrub species include Yucca baccata (Engelm.) Tre., Nolina microcarpa Wats., Agave sp., Rhus trilobata Nutt., and Fallugia paradoxa (D. Don) Endl. Typical species under conditions of rockiness and thin soil mantle are Mimosa sp., Opuntia spp., Applopappus sp., and Dasylirion wheeleri Wats. The vegetation is clearly shrub-dominated and grass species never form pure stands.

\section{Methods}

In November 1980, 126 leaders representative of the current year's growth were randomly selected from 20 individual plants located on both north and south aspects and hand-clipped. They were clipped at the point of attachment to the stem and air-dried for 2 weeks. Measurements of twig length and diameter were recorded. Lengths were measured to the nearest $0.1 \mathrm{~cm}$. Diameters were measured to the nearest $0.01 \mathrm{~cm}$ at $1 \mathrm{~cm}, 3 \mathrm{~cm}$ and $5 \mathrm{~cm}$ from the base of the twig using a vernier caliper. Leaves were then separated from leaders and weighed to the nearest $0.001 \mathrm{~g}$. There were no significant differences $(P<0.05)$ in leader length, diameters or weight from plants on north and south exposures. Consequently, data were combined for the regression analysis.

Leader diameter-length-weight relations were established through all possible regression analysis (Draper and Smith 1966). Leader weight was the dependent variable. Leader length, diameters at 1,3 and $5 \mathrm{~cm}$, and percent leaf weight were the independent variables. They were used individually and in all possible combinations. Another set of equations was developed through transformation to logarithmic form.

\section{Results}

Regression equations relating air-dry leader diameters at 1,3 , and $5 \mathrm{~cm}$ from the base, leader length, and percent leaf weight to leader dry weight were established from samples of 126 leaders. Diameters $5 \mathrm{~cm}$ from the base for samples ranged from 0.8 to 2.6 $\mathrm{mm}$. Length ranged from 5.5 to $25.7 \mathrm{~cm}$ and weight ranged from 0.13 to $2.34 \mathrm{~g}$. A simple linear regression equation providing the best description of data was in the general form $\bar{y}=\mathbf{B}_{\mathbf{0}}+\mathbf{B}_{1} \mathbf{x}$. The highest single predictor $\left(r^{2}=0.85\right)$ of leader weight was leader diameter measured $5 \mathrm{~cm}$ from the base. The regression equation obtained was $\hat{y}=-0.8+10.03 \times$ (Table 1). Logarithmic transformation of data improved predictive power slightly $\left(r^{2}=0.87\right)$. A lower coefficient of determination $\left(r^{2}=0.80\right)$ was obtained when leader length was used instead of leader diameter as an independent variable and the regression equation was $\hat{y}=+0.32+0.08 \times$ (Table 1).

\section{Discussion}

Higher correlation of weight with diameter than length for mountain mahogany was in agreement with data of Provenza and Urness (1981) for blackbrush (Coleogyne ramosissima Torr.), Lyon (1970) for serviceberry (Amelanchier alnifolia Nutt.), Basile and Hutchings (1966), and Ferguson and Marsden (1977) for bitterbrush (Purshia tridentata [Pursh.] D.C.).

Several authors have emphasized the effect of site, years, browsing pressure, overstory canopy, and years on these twig weightdiameter-length relationships (Basile and Hutchings 1966, Ferguson and Marsden 1977, Halls and Harlow 1971, Lyon 1970, Peek 1971, and Rutherford 1979). From these studies, we should be warned that frequent checks may be necessary to assure application of the most appropriate equation. For instance, data from bitterbrush plants in southeastern and southwestern Idaho revealed similar y intercepts, but rather large differences in regression coefficients (Basile and Hutchings 1966, Ferguson and Marsden (1977). In other cases, general equations may apply across a wide array of conditions (Bartolome and Kosco 1982, Provenza and Urness 1981). Because we sampled at only the one date, it is not possible to know how general our results are.

The leader diameter-weight regression equation yielded higher accuracy and predictability than the length-weight equation for hairy mountain mahogany. However, leader lengths were easier to measure in the field than diameters.

Use of these procedures for utilization estimates rests on the assumption that leaves are not eaten independently of leaders (Ruyle et al. 1983, Smith and Urness 1962). Leaves contributed 
from 23 to $70 \%$ of total leader weight of hairy mountain mahogany in this study. If browsing animals strip leaves off, then these methods would not be appropriate, unless leaves were accounted for (Ruyle et al. 1983).

\section{Literature Cited}

Bartolome, J.W., and B.H. Kosco. 1982. Estimating browse production by deerbrush (Ceanothus integerrimus). J. Range Manage. 35:671-672.

Badile, J.V., and S.S. Hutchinge. 1966. Twig diameter-length-weight relations of bitterbrush. J. Range Manage. 19:34-38.

Draper, N.R., and H. Smith. 1966. Applied regression analysis. John Wiley and Sons, New York.

Ferguson, R.B., and J.A. Marden. 1977. Estimating overwinter bitterbrush utilization from twig diameter-length-weight relations. J. Range Manage. 30:231-236.

Halls, L.K., and R.F. Harlow. 1971. Weight-length relations in flowering dogwood. J. Range Manage. 24:236-237.

Herbel, C.H., R.S. Steger, and W.L. Gould. 1974. Managing semidesert range of the Southwest. New Mexico State Univ. Coop. Ext. Serv. Circ. 456.

Lyon, J.L. 1970. Length- and weight-diameter relations of serviceberry twigs. J. Wildl. Manage. 34:456-460.
Moir, W.H. 1963. Vegetational analyses of three southern New Mexico mountain ranges. Unpublished M.S. thesis. New Mexico State Univ., Las Cruces.

Pauleen, H.A., and F.N. Ares. 1962. Grazing values and management of black grama and tobosa grasslands and associated shrub ranges of the Southwest. USDA Tech. Bull. 1270.

Peek, J.M., L.W. Krefting, and J.C. Tappeiner. 1971. Variation in twig diameter-weight relationships in northern Minnesota. J. Wildl. Manage. 35:501-507.

Provenza, F.D., and P.J. Umess. 1981. Diameter-length-weight relations for blackbrush (Coleogyne ramosissima) branches. J. Range Manage. 34:215-217.

Rutherford, M.C. 1979. Plant-based techniques for determining available browse and browse utilization: A review. Bot. Rev. 45:203-228.

Ruyle, G.B., J.E. Bowns, and A.F. Sehlundt. 1983. Estimating snowberry (Symphoricarpos oreophilus) utilization by sheep from twig diameterweight relations. J. Range Manage. 36:472-474.

Smith, A.D., and P.J. Urneas. 1962. Analyses of the twig length method of determining utilization. Utah State Dept. of Fish and Game Pub. 62-9.

Telfer, E.S. 1969. Twig weight-diameter relations of serviceberry twigs. J. Wildl. Manage. 34:446-460. 